\title{
ОПТИМІЗАЦІЯ ЕКСПЛУАТАЦІЇ СУДНОВИХ СИСТЕМ КОМФОРТНОГО КОНДИЦІОНУВАННЯ ПОВІТРЯ ЗА РАХУНОК ВИКОРИСТАННЯ ПРОГРАМОВАНИХ ЛОГІЧНИХ КОНТРОЛЕРІВ
}

\author{
Ю. О. Очеретяний ${ }^{1}$, А.І. Головань ${ }^{2}$, Ю.М. Федорова ${ }^{1}$ \\ ${ }^{1}$ Національний університет «Одеська морська академія», вул. Дідріхсона 8, Одеса, 65029, Україна \\ ${ }^{2}$ Одеський національний морський університет, вул. Мечникова 34, Одеса, 65029, Україна \\ ORCID: ${ }^{1}$ https://orcid.org/0000-0002-8239-7587, ${ }^{2}$ https://orcid.org/0000-0001-6589-4381 \\ e-mail: ${ }^{1}$ och2008@ukr.net; ${ }^{2}$ andrew.golovan@gmail.com
}

Copyright (C) 2020 by author and the journal "Automation of technological and business - processes. This work is licensed under the Creative Commons Attribution International License (CC BY). http://creativecommons.org/licanses/by/4.0

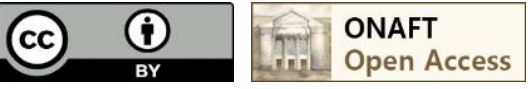

\section{DOI: https://doi.org/10.15673/atbp.v12i1.1704}

Анотація. Різноманітний кліматичний режим Світового океану та стан водної поверхні грають істотну роль у формуванні мікроклімату внутрішньосуднових приміщень. Гідрометеорологічні умови, викликаючи різні фізіологічні відхилення від норми у пасажирів і екіпажу, можуть створити у перших незадоволення морською подорожжю, а другим ускладнити виконання службових обов'язків по управлінню судном. Основним призначенням судової системи комфортного кондиціонування повітря (ССККП) $\epsilon$ автоматична підтримка заданих параметрів мікроклімату внутрішньосуднових приміщень незалежно від зміни в часі та просторі зовнішніх гідрометеорологічних умов навколишнього середовища. До найбільш поширених на морському флоті способам автоматичного керування $i$ регулювання ССККП відноситься спосіб регулювання иляхом зміни температури холодоносія, яка в свою чергу регулюється зміною продуктивності компресора за допомогою системи керування «Uпіsаb». Дана система допускає регулювання продуктивності компресора в автоматичному режимі, однак, виникає необхідність в завданні значення температури холодоносія механіком в залежності від мінливих зовнішніх $i$ внутрішніх умов навколитнього середовища. Запропонована модель використання програмованих логічних контролерів в якості генератора сигналу управління завданням температури холодоносія дозволяє вирішити проблему коректного регулювання і таким чином збільиити надійність та енергоефективність експлуатації ССККП.

Abstract. The diverse climatic regime of the oceans and the state of the water surface play a significant role in the formation of the microclimate of intravascular spaces. Hydro-meteorological conditions, causing various physiological deviations from the norm in passengers and crew, can in the first place create dissatisfaction with the sea voyage, and in the second complicate the performance of official duties for managing the ship. The primary purpose of the Comfortable Air Conditioning system is to automatically support the set microclimate parameters of intravascular premises, regardless of changes in the weather and space of external environmental meteorological conditions. The most common methods in the Navy are the automatic control and regulation of the SCACS control method by changing the temperature of the coolant, which in turn is governed by the change in compressor performance by the Unisab control system. This system allows the regulation of the compressor productivity in the automatic mode, however, there is a need to set the value of the temperature of the coolant by a mechanic, depending on the changing external and internal environmental conditions. The proposed model of the use of programmable logic controllers as a generator of the control signal of the temperature control of the cold carrier allows to solve the problem of correct regulation and thus to increase the reliability and energy efficiency of operation of the SCACS.

Ключові слова: суднова система комфортного кондиціонування повітря; суднова холодильна установка; гідрометеорологічні умови; система керування; холодоносій; енергоефективність; програмовані логічні контролери

Keywords: ship's system of comfortable air conditioning; ship refrigeration unit; hydrometeorological conditions; control system; cold carrier; energy efficiency; programmable logic controllers

\section{1. Вступ}

Відомо, що комфортне кондиціонування повітря на суднах забезпечує процес підтримання у всіх житлових приміщеннях заданих комфортних значень параметрів повітря (найчастіше температури і вологості) незалежно від зміни умов навколишнього середовища та в середині приміщень. 
При температурі зовнішнього повітря нижче ніж $10^{\circ} \mathrm{C}$ ССККП повинна працювати у режимі обігріву, а при температурі вище $23{ }^{\circ} \mathrm{C}$ - у режимі охолодження. В інтервалі температур від $10^{\circ} \mathrm{C}$ до $23{ }^{\circ} \mathrm{C}-$ у режимі вентиляції.

Таким чином кондиціонування включає тепло вологу обробку повітря, забезпечення його нормального хімічного складу, доведення повітря до фізіологічних кондицій (озонування, іонізацію). У суднових приміщеннях параметри повітря змінюються інтенсивніше, ніж у берегових, у зв'язку з їх малим обсягом і високою теплопровідністю огороджувальних поверхонь. Мікроклімат внутрішньосуднових приміщень суттєво впливає на самопочуття людей, що постійно знаходяться в них, тому існує необхідність у підтримці комфортних умов в таких приміщеннях. Це забезпечується за допомогою судової системи комфортного кондиціонування повітря (ССККП). Ці системи здатні підтримувати комфортні значення температури, вологості і рухливості повітря і забезпечують необхідний повітрообмін. Усі ССККП мають установки для приготування тепло і холодоносія, та для тепло вологої обробки повітря і його подачі в приміщення (елементи центрального кондиціонера), повітроводи; розподільників повітря; системи контролю та управління.

Тепло вологий стан каютного повітря визначається не тільки тепло і волого виділеннями лю-дей, а й теплопритоками (тепловтратами) через огородження приміщень, залежними від зовнішніх кліматичних умов. На тепловідчуття людини впливають температура i відносна вологість повітря, швидкість його руху і температура огороджувальних поверхонь. Чи не будь-яке поєднання цих параметрів забезпечує комфортні умови, кожен параметр може змінюватися тільки в обмежених межах. Так, відносна вологість повинна бути $50 \pm 10 \%$, швидкість повітря 0,15 м / с (допускається до 0,5 м / c), різниця температур повітря в приміщенні і огороджувальних поверхонь не повинна перевищувати $\pm 4^{\circ} \mathrm{C}$. Зазвичай різниця температур каютного і припливного повітря дорівнює $5 \ldots 10{ }^{\circ} \mathrm{C}$. При спрямованих потоках повітря його температура в зоні проживання повинна бути не нижче $22{ }^{\circ} \mathrm{C}$ i відрізнятися від середньої температури в приміщенні не більше ніж на $5^{\circ} \mathrm{C}$. При високій температурі зовнішнього повітря (34 ... $40 \circ \mathrm{C})$ слід підтримувати в приміщенні температуру не нижче $27^{\circ}$ С. При фізичній роботі і в період сну рекомендується знизити температуру на $2 \ldots 3^{\circ} \mathrm{C}$, наближаючи їі до нижньої межі зони комфорту (20 $\left.{ }^{\circ} \mathrm{C}\right)$. Слід зазначити, що згідно з санітарними правилами, значення результуючих температур приміщень судів необме-женого району плавання лежить у межах від $18,1^{\circ} \mathrm{C}$ - для холодного періоду, до $24,2{ }^{\circ} \mathrm{C}$ - для теплого періоду. Значення норм мікроклімату для суднових приміщень доведено у табл. 1.

Таблиця 1 - Значення норм мікроклімату для суднових приміщень

\begin{tabular}{|c|c|c|c|c|}
\hline \multirow{2}{*}{$\begin{array}{c}\text { Район } \\
\text { плавания }\end{array}$} & \multirow{2}{*}{$\begin{array}{l}\text { Период } \\
\text { года }\end{array}$} & \multicolumn{3}{|c|}{ Результирующая температура, ${ }^{\circ} \mathrm{C}$} \\
\hline & & Нижняя граница & Рекомендуемая расчетная & Верхняя граница \\
\hline Тропики & - & 22,6 & 24,2 & 25,7 \\
\hline \multirow{2}{*}{ Субтропики } & Теплый & 20,8 & 22,0 & 23,2 \\
\hline & Холодный & 17,7 & 19,2 & 20,7 \\
\hline \multirow{2}{*}{$\begin{array}{l}\text { Умеренные } \\
\text { широты }\end{array}$} & Теплый & 17.7 & 19,8 & 22,0 \\
\hline & Холодный & 15,9 & 18,1 & 20,3 \\
\hline \multirow{2}{*}{$\begin{array}{l}\text { Северные } \\
\text { (приполярные) }\end{array}$} & Теплый & 18,3 & 20,0 & 21,6 \\
\hline & Холодный & 17,6 & 19,0 & 20,4 \\
\hline \multirow{2}{*}{ Неограниченный } & Теплый & 22,6 & 24,2 & 25,7 \\
\hline & Холодный & 15,9 & 18,1 & 20,3 \\
\hline
\end{tabular}

Різноманітний кліматичний режим Світового океану і стан водної поверхні грають дуже істотну роль у формуванні мікроклімату внутрішньосуднових приміщень.

Мікроклімат таких приміщень залежить від температури і вологості зовнішнього повітря, на величинах яких відбивається вплив ступеня нагрівання бортів і палуби судна, яка визначається значною мірою припливом прямої сонячної радіації. Ця залежність виражається головним чином, через вентилювання суднових приміщень зовнішнім повітрям, обробленим ССККП. Вологість повітря дуже помітно позначається на роботі різних вентиляційних пристроїв. У тих вентиляційних відділеннях, де $\epsilon$ повітроохолоджувачі використовують воду зі зниженою температурою $\left(8 \div 12^{\circ} \mathrm{C}\right)$, може статися і відбувається конденсація вологи на поверхнях теплообмінних апаратів, а в разі недостатньої теплової ізоляції - і на підвідних магістралях системи охолодження. Утворена в результаті цього вода накопичується на поверхнях і розтрубах вентиляції, якщо дренажна система не забезпечує повноцінного стоку.

Облік таких кліматичних характеристик, як мінімальні і максимальні температури і вологість повітря, від яких залежить ентальпія, є необхідним для роботи систем кондиціонування повітря на морських суднах.

Кліматичні умови тропічних широт створюють певний мікроскопічний режим і в інших вну-трішніх приміщеннях судна. Наприклад, від нагрівання бортів і палуб судна сонячними променями в денні години, а також в наслідок спільного впливу високої температури і від-відносної вологи повітря у внутрішніх приміщеннях судна виникає задуха, яка без кондиціонування повітря важко переноситься людьми. У нічні години, якщо відсутній кондиціонер в наслідок великого вмісту вологи повітря в каютах з'являється вогкість. Вона особливо помітна на постільній білизні, на обмундируванні та інших предметах з тканин, і якщо їх вдень не виносить на палубу, вони покриваються пліснявою. 
Небажаної $є$ і велика сухість повітря в суднових приміщеннях у зв'язку з широким використанням синтетичних матеріалів для обробки останніх на сучасних суднах. При малому значенні відносної вологості повітря (22 $\div 24 \%)$ виникають поля статичної електрики великої напруженості, які негативно діють на самопочуття і здоров'я екіпажу та пасажирів. Таким чином, гідрометеорологічні умови, викликаючи різні фізіологічні відхилень від норми у пасажирів і екіпажу, можуть створити у перших незадоволення морською подорожжю, а другим ускладнити виконання службових обов'язків по управлінню судном.

Успішна експлуатація сучасних ССККП можлива тільки при використанні систем ав-томатізаціі . Автоматичні пристрої значно спрощують роботу персоналу, обслуговуючого ССККП - точно підтримують заданий температурновологовий режим, скорочують експлуатаційні витрати, збільшують термін роботи холодильних компресорів, забезпечують захист ССККП і холодильної установки від аварій.

Такі автоматичні пристрої виконують функції - сигналізації, контролю, захисту, регулювання і управління.

При повній автоматизації всі функції управління і контролю передаються автоматичним системам без безпосередньої участі людини. Пристрої автоматики контролюють режим роботи холодильної установки (показують і записують), автоматичним регулюванням підтримують задані параметри. За допомогою звукових і світлових сигналів сигналізують про включення окремих пристроїв, а також попереджають про небезпечний відхиленні параметрів.

Таким чином, метою даної роботи є визначення можливостей оптимізації та збільшення енергоефективності експлуатації ССККП за допомогою оптимального управління програмованих логічних контролерів, в умовах, де постійно змінюються гідрометеорологічні умови.

\section{2. Аналіз проблеми та постановка завдання}

Добре відомо, що в даний час на суднах морського флоту найбільше використовується система Unisab III.

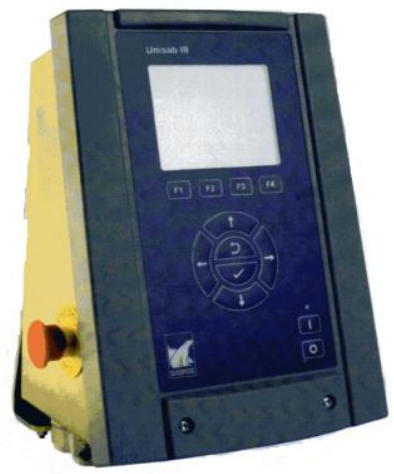

Рис. 1 - Зовнішній вигляд сучасної системи керування ССККП Unisab III

Unisab III - це комп'ютерна система управління та поточного контролю, яка допускає декілька способів регулювання продуктивності компресора по тискам і температурі. При цьому, регулювання продуктивності може здійснюватися як вручну, так і автоматично. Слід так само відзначити, що навіть в автоматичному режимі роботи, завдання значення температури вихідної охолоджуючої води проводиться обслуговуючим персоналом, в залежності від оцінки впливу зовнішніх гідрометеорологічних умов, сумарних теплоприпливів, що потрапляють в судно із зовні, а також внутрішніх тепло і волого надходжень. При цьому значення температури покидаючої чиллер охолоджуючої води, згідно суднової технічної специфікації, знаходиться в межах $6 \div 12{ }^{\circ} \mathrm{C}$. Відповідно більш низькі значення, що встановлюються оператором відповідають більш високим показникам температури і відносній вологості навколишнього середовища, і навпаки, при більш низьких значеннях встановлюється більш високе значення температури холодоносія.

Схема сучасного методу управління ССККП наведена на рисунку 2.

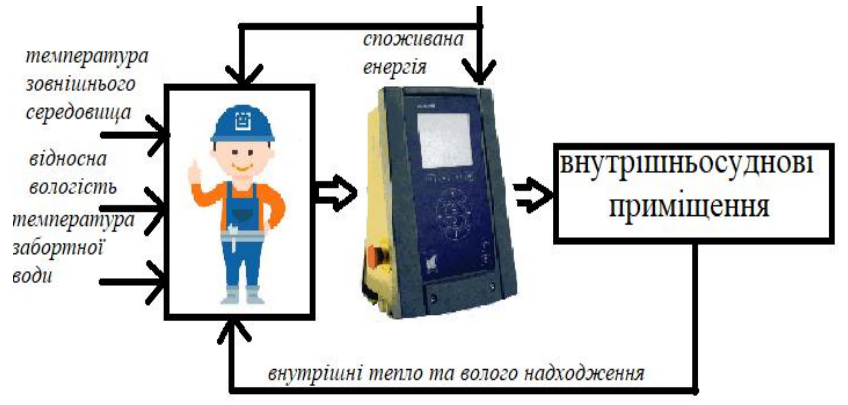

Рис. 2 - Схема сучасного методу управління ССККП

Як видно зі схеми, на даний час прийняття рішень 3 управління, і як слідство відповідальність за енергоефекктивну та екологічну складову процесу з експлуатації ССККП повністю лежить на людині - операторі. 
При цьому, людині не завжди вдається об'єктивно оцінити усі обставини постійно змінних зовнішніх та внутрішніх умов, та прийняти вірне рішення що до енергоефективного керування. Слід зазначити, що під енергетичною эфективністю розуміють раціональне використання (витрачання) энергетичних ресурсів.

Таким чином безпосередній практичний інтерес представляє питання автоматичного управління завданням значень температури холодоносія, без участі в цьому процесі людини. Це допоможе виключити можливі помилки, так званий людський фактор, а так само підвищити надійність та енергоефективність експлуатації систем СККВ. Передбачається також передача даних термодинамічних пара-метрів у реальному режимі часу за допомогою бездротових протоколів на будь-який Android або Ios пристрій оператора. Внаслідок чого, механік, який обслуговує систему, може здійснювати повноцінний контроль за роботою системи, незалежно від свого місцезнаходження. Система зв'язку так само робить можливим під'єднати-ня Unisab III до програмованого контролера або персонального комп'ютера системи центра-лізованного контролю, управління і реєстрації даних.

Тому у даній роботі пропонується можливість застосування програмованих логічних контролерів як допоміжних модулів управління ССККП.

Для реалізації системи моніторингу в "жорсткому" реальному часі обраний ПЛК серії Inline ILC 130 ETH німецької фірми Phoenix Contact, який виконаний відповідно до загально-прийнятих стандартів програмування МЕК 61131-3 і технології передачі даних Ethernet, підтримує паралельний обмін даними з ОРС -Серверами і комунікацію з кінцевими пристроями, що підтримують протокол ТСР / IP.

Контролери Unisab III конфігуруються на заводі-виробнику. Вони оснащені комунікаційним обладнанням і протоколами зв'язку для моніторингу та управління широким асортиментом компресорів, холодильних машин i теплових насосів. Також з їх допомогою здійснюється діагностика обладнання та обробка даних (Рис. 3).

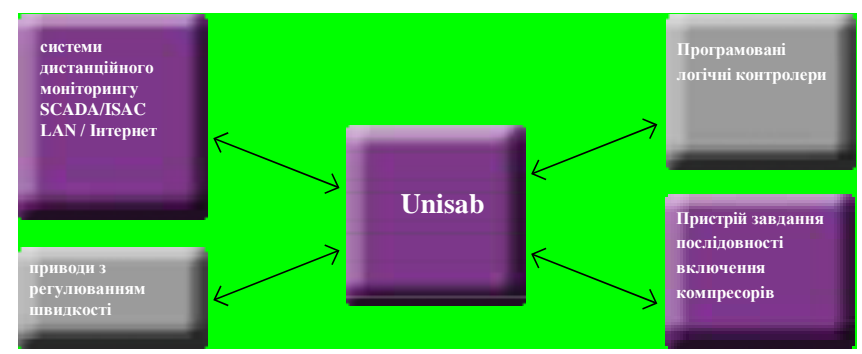

Рис. 3 - Підключення контролера Unisab III до зовнішнього контрольно-вимірювального обладнання

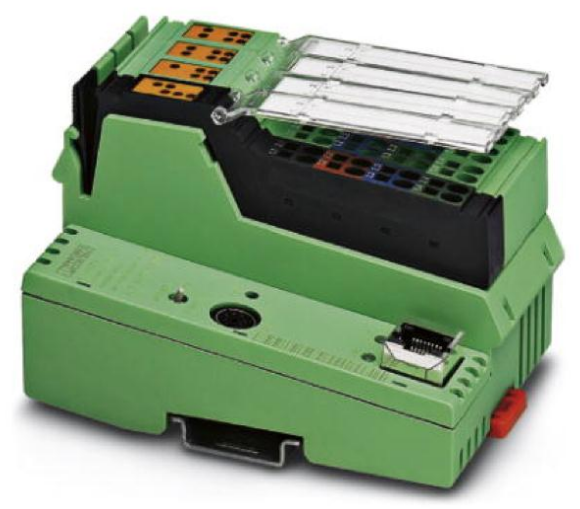

Рис. 4 - Зовнішній вигляд ПЛК «Phoenix»

Основні характеристики ПЛК ILC 130 ETH:

- швидкість обробки 90 мкс на 1000 інструкцій для логічного типу даних і 1,7 мс на 1000 інструкцій для змішаного типу даних;

- один INTERBUS інтерфейс і один Ethernet інтерфейс;

- 192 Кбайт пам'яті програм і 192 Кбайт пам'яті даних, 8 Кбайт незалежної пам'яті даних;

- 8 прямих входів і 4 прямих виходу;

- максимум 2048 точки введення / виведення;

- харчування 24 B;

- вбудований web / FTP server;

- підтримка ОРС.

ILC 130 ЕTH має ступінь захисту IP20 і здатний функціонувати при наступних умовах навколишнього середовища:

- температура навколишнього повітря $-25^{\circ} \mathrm{C}-55^{\circ} \mathrm{C}$; 
- допустима відносна вологість повітря 10\% - 95\%;

- тиск повітря 70 кПа - 106 кПа (До 3000 м над рівнем моря);

- вібрація $5 \mathrm{~g}$.

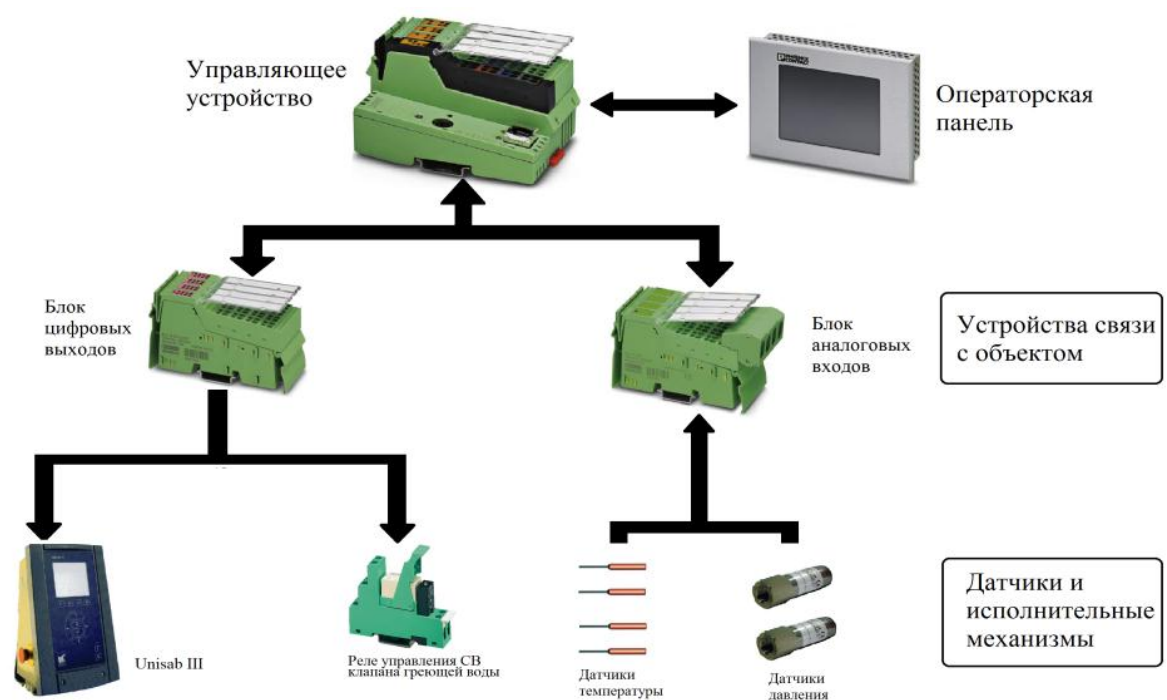

Рис. 5 - Функціональна схема запропонованого методу системи управління за рахунок використання ПЛ-контролерів

Запропонований метод оптимізації експлуатації ССККВ за допомогою використання ПЛК, представлений у вигляді схеми на рисунку 4, полягає в наступному.

Для зв'язку між ПЛК та UNISAB III використовується протокол Danbus. Цей протокол зарезервований для розподілу навантаження (послідовності включення) в установках до 14 Unisab II та Unisab III.

Інтерфейс Danbus можна використовувати для зв'язку з системами моніторингу на базі ПК через перетворювач RS2LAN. Перетворювач RS2LAN розроблений для комунікації з ОРC, тобто підтримка ОРС в системі моніторингу на базі ПК є обов'язковою умовою.

Danbus заснований на RS485, який є електричним стандартом для послідовного зв'язку. RS485 використовує 2провідний кабель і повинен бути приєднаний відповідно до специфікацій інструкції Unisab (кабель від Unisab до Unisab тощо). Перетворювач не потрібен, якщо Danbus використовується тільки для послідовності контролерів Unisab.

Сигнали, що надходять у контролер від датчиків температур i влажностей зовнішніх $\mathrm{i}$ внутрішніх гідрометеорологічних параметрів навколишнього середовища, а також значень параметрів продуктивності $\mathrm{i}$ споживаної потужності компресора, обробляються в контролері за допомогою відповідного алгоритму і програми тепловологого розрахунку необхідної холодопотреби та дійсної холодопродуктивності. Чисельне значення холодопотребності порівнюється зі значенням його дійсної холодопродуктивності для того, щоб зробити обгрунтований висновок про технічний стан холодильної установки і далі, при наявності підстав, перейти до технічної діагностики компонентів всієї холодильної системи. I як наслідок отримати дійсний холодильний коефіцієнт, що слугує показником енергетичної ефективності СХУ ССККВ.

3 точки зору управління і діагностики цей підхід дозволить мати достовірні оперативні дані що до холодопродуктивності, споживання електричної енергії, а також по питомій витраті енергії на вироблення холоду, крім того, користувач отримає динаміку зміни цих величин за обраний період часу.

На підставі, отриманих від датчиків, зовнішніх і внутрішніх параметрів навколишнього середовища і відповідних функціональних залежностей, алгоритма і програми обробки даних ПЛК формує і за допомогою відповідного протоколу передачі даних, передає керуючий сигнал оптимального значення температури хлалдоносія системі Unisab III для подальшої її реалізації в СХУ ССККВ, яка задає параметри управління значенням продуктивності компресора.

Таким чином метою даної роботи $є$ отримання графіків функцій та відповідних функціональних залежностей, що пов'язують воєдино умови впливу зовнішніх ГМУ, параметрів температури і вологості внутрішньосуднових приміщень, вплив зовнішніх і внутрішніх теплопритоків з температурою холодоносія.

$$
\begin{gathered}
T_{o x л .6}=f\left(t_{o c}, \varphi_{o c}, t_{\text {пом }}, N_{\text {nотр }}\right) \\
T_{\text {пом }}=f\left(t_{\text {oxл. } 6}\right)
\end{gathered}
$$

Для досягнення поставленої мети використовується методика проведення повного факторного експерименту. Експериментальні дослідження проводилися на борту пасажирського теплохіда «BERLIN», загальною сумарною холодопродуктивністю ССККВ 1650000 Ккал / год., В період з 08.01.19 по 26.03.19., в умовах плавання судна в різних районах Світового океану з часто змінюючимися зовнішніми гідрометеорологічними умовами. 


\section{3. Проведення повного факторного експерименту}

Для визначення впливу зовнішніх гідрометеорологічних умов на енергетичну ефективність експлуатації ССККВ необхідно досліджувати вплив таких чинників, як температура навколишнього середовища -Тн.с, температура забортноъ води - Т з.в , температура охолоджуваючоъ води (холодоносыя) - Т о.в., та отримати У (Рис. 6).

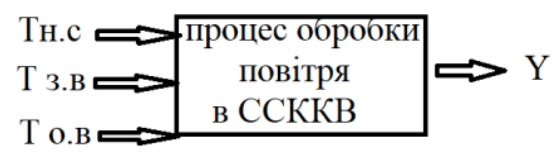

\section{Рис. 6 - Функціональна схема отримання критерія оптимізації}

Інтервали варіювання фактора визначаються на основі попередніх експериментів. Ефективність обробки У - це критерій оптимізації. Так як в умовах судна дяли два паралельно працюючих СХУ ССККВ, то факторний експеремент, за цим прикладом, проводився тричі: для першого і другого ССККВ, що працюють паралельно і для другого ССККВ, що працює самостійно. Фактори записують на верхньому і нижньому рівнях у вигляді таблиці.

Таблиця 2 - Інтервали варіювання фактора для першого ССККВ

\begin{tabular}{|l|l|l|}
\hline Фактори & $\operatorname{Min}(-1)$ & $\operatorname{Max}(+1)$ \\
\hline X1(tнс) & 26.2 & 34.9 \\
\hline X2(tзв) & 23 & 26 \\
\hline X3(tов) & 12.1 & 14 \\
\hline
\end{tabular}

При відомому значенні числа фактора можна знайти число дослідів для реалізації всіх можливих поєднань рівнів і факторів за формулою:

$$
\mathrm{N}=2^{\mathrm{n}}=2^{3}=8,
$$

де $\mathrm{N}$ - кількість експерементів; $\mathrm{n}$ - кількість факторів.

План експерименту задамо у вигляді таблиці. Для експеремнта такого типу таблиця має вигляд:

Таблиця 3 - План експерименту

\begin{tabular}{|c|c|c|c|c|c|c|c|c|c|c|c|}
\hline$\#(1)$ & $\mathrm{x} 0$ & $\mathrm{x} 1$ & $\times 2$ & $x 3$ & $x 1 \times 2$ & $\times 2 \times 3$ & $\mathrm{x} 1 \times 3$ & $x 1 \times 2 \times 3$ & Y1 & Y2 & Ymed \\
\hline 1 & 1 & 1 & 1 & 1 & 1 & 1 & 1 & 1 & 16.3 & 16 & 16.15 \\
\hline 2 & 1 & -1 & 1 & 1 & -1 & 1 & -1 & -1 & 17.1 & 17.4 & 17.25 \\
\hline 3 & 1 & 1 & -1 & 1 & -1 & -1 & 1 & -1 & 17.5 & 17.8 & 17.65 \\
\hline 4 & 1 & -1 & -1 & 1 & 1 & -1 & -1 & 1 & 17.5 & 17.8 & 17.65 \\
\hline 5 & 1 & 1 & 1 & -1 & 1 & -1 & -1 & -1 & 17.3 & 17 & 17.15 \\
\hline 6 & 1 & -1 & 1 & -1 & -1 & -1 & 1 & 1 & 17.3 & 17.5 & 17.4 \\
\hline 7 & 1 & 1 & -1 & -1 & -1 & 1 & -1 & 1 & 15.3 & 15.8 & 15.55 \\
\hline 8 & 1 & -1 & -1 & -1 & 1 & 1 & 1 & -1 & 18.3 & 19 & 18.65 \\
\hline & & & & & & & & & & & 137.45 \\
\hline
\end{tabular}

Запишемо для повного фактичного експеремнта рівняння регресії, яке описує процес обробки повітря:

$$
\mathrm{Y}=\mathrm{b}_{0}+\mathrm{b}_{1} \mathrm{x}_{1}+\mathrm{b}_{2} \mathrm{x}_{2}+\mathrm{b}_{3} \mathrm{x}_{3}+\mathrm{b}_{12} \mathrm{x}_{1} \mathrm{x}_{2}+\mathrm{b}_{23} \mathrm{x}_{2} \mathrm{x}_{3}+\mathrm{b}_{13} \mathrm{x}_{1} \mathrm{x}_{3}+\mathrm{b}_{123} \mathrm{x}_{1} \mathrm{x}_{2} \mathrm{x}_{2}
$$

Визначення коефіціснтів рівняння регресії

Визначимо вільний член за формулою:

Визначимо коефіцієнти взаємодії за формулою:

$$
\begin{aligned}
\mathrm{b}_{0} & =\sum \mathrm{Y}_{\mathrm{cp}} / \mathrm{N} \\
\mathrm{b}_{0} & =137.45 / 8
\end{aligned}
$$

Рівняння регресії після розрахунку має вигляд:

$$
\mathrm{b}_{1}=\sum \mathrm{x}_{\mathrm{i}} \cdot \mathrm{Y}_{\mathrm{icp}} / \mathrm{N}
$$

$$
\mathrm{Y}=17.18125-0.55625 \mathrm{x}_{1}-0.19375 \mathrm{x}_{2}-0.00625 \mathrm{x}_{3}+0.21875 \mathrm{x}_{1} \mathrm{x}_{2}-0.28125 \mathrm{x}_{2} \mathrm{x}_{3}+0.28125 \mathrm{x}_{1} \mathrm{x}_{3}-0.49375 \mathrm{x}_{1} \mathrm{x}_{2} \mathrm{x}_{3}
$$

\section{Перевірка відтворюваності процесу і значущості коефіцієнтів регресії}

Для перевірки відтворюваності процесу і проведення статичних оцінок передбачаються паралельні досліди. Якщо кожен досвід повторюється однакове число раз, то таке повторення називають паралельним дублюванням. При однаковому числі паралельних дослідів на кожному поєднанні рівнів і факторів розраховуються построкові дисперсії і перевіряється їх однорідність за критерієм Кохрена.

Однорідність перевіряється шляхом вибору максимального значення 3 порядкової дисперсій і визначення для нього розрахункового критерію Кохрена.

Построкові дисперсії розраховуємо за формулою: 


$$
\mathrm{S}_{\text {yi }}^{2}=\left(\sum\left(\mathrm{Y}_{1 э к с}-\mathrm{Y}_{\text {ср.экс }}\right)^{\wedge} 2+\left(\mathrm{Y}_{2 э к с}-\mathrm{Y}_{\text {ср.экс }}\right)^{\wedge} 2\right) /(\mathrm{H}-1),
$$

де $\mathrm{H}=2$ - кількість паралельних дослідів.

$\mathrm{S}_{\mathrm{y1}}^{2}=(16.3-16.15)^{\wedge} 2+(16-16.15)^{\wedge} 2 /(2-1)=0.045$

$\mathrm{S}^{2}{ }_{\mathrm{y} 2}=(17.1-17.25)^{\wedge} 2+(17.4-17.25)^{\wedge} 2 /(2-1)=0.045$

$\mathrm{S}_{\mathrm{y} 3}^{2}=(17.5-17.65)^{\wedge} 2+(17.8-17.65)^{\wedge} 2 /(2-1)=0.045$

$\mathrm{S}^{2}{ }_{\mathrm{y} 4}=(17.5-17.65)^{\wedge} 2+(17.8-17.65)^{\wedge} 2 /(2-1)=0.045$

$\mathrm{S}^{2}{ }^{2}=(17.3-17.15)^{\wedge} 2+(17-17.15)^{\wedge} 2 /(2-1)=0.045$

$\mathrm{S}^{2}{ }_{\mathrm{y} 6}=(17.3-17.4)^{\wedge} 2+(17.5-17.4)^{\wedge} 2 /(2-1)=0.02$

$\mathrm{S}_{\mathrm{y} 7}^{2}=(15.3-15.55)^{\wedge} 2+(15.8-15.55)^{\wedge} 2 /(2-1)=0.125$

$\mathrm{S}^{2}{ }_{\mathrm{y} 8}=(8.3-18.65)^{\wedge} 2+(19-18.65)^{\wedge} 2 /(2-1)=0.245$

$\sum \mathrm{S}_{\mathrm{y}}^{2}=0.615$

Мах значення $\mathrm{S}_{\text {y8 }}^{2}=0.245$

Визначивши максимальне значення порядкової дисперсії обчислюємо для неї розрахунковий критерій Кохрена:

$$
\begin{gathered}
\mathrm{G}_{\mathrm{p}}=\mathrm{S}_{\mathrm{y} \max }^{2} / \sum_{\mathrm{i}}^{2} \mathrm{~S}_{\mathrm{i}} \\
\mathrm{G}_{\mathrm{P}}=0.245 / 0.615=0.4
\end{gathered}
$$

Висновок про однорідність робимо на основі порівняння отриманого розрахункового критерію Кохрена 3 табличним значенням.

Визначимо дисперсію експерименту:

$$
\begin{aligned}
& S_{y \text { cp }}^{2}=\sum S_{i}^{2} / N \\
& S_{y \text { cp }}^{2}=0.615 / 8=0.077
\end{aligned}
$$

\section{Визначення дисперсії коефіціснтів рівняння регресії}

Деякі з обчислень за експерементальними даними коефіцієнтів рівняння регрессіі по абсолютній величині можуть виявитися дуже малими в порівнянні з іншими, тобто одні з коеффііціентов будуть значимі, а інші - ні.

Для перевірки гіпотези щодо статичної значущості коефіцієнтів рівняння регресії розрахуємо дисперсію коефіцієнтів за формулою:

$$
\begin{gathered}
\mathrm{S}_{\mathrm{bi}}^{2}=\sum \mathrm{S}_{\mathrm{ycp}} / \mathrm{N} \cdot \mathrm{M}, \\
\mathrm{S}_{\mathrm{bi}}^{2}=0.077 / 8 \cdot 2=0.0048,
\end{gathered}
$$

де $\mathrm{M}=2$ - кількість паралельних серій.

Для оцінки значущості коефіцієнтів з довірчого інтервалу обчислюємо для кожного коефіцієнта за формулою:

$$
\begin{gathered}
\Delta \mathrm{b}_{\mathrm{i}}= \pm \mathrm{t} \cdot \sqrt{ } \mathrm{S}_{\mathrm{bi}}^{2}, \\
\Delta \mathrm{b}_{\mathrm{i}}= \pm 2.31 \cdot \sqrt{ } 0.0048= \pm 0.16
\end{gathered}
$$

де $\mathrm{t}=2.31$ - критерій Стьюдента.

Довірчий інтервал $\Delta \mathrm{b}_{\mathrm{i}}$ однаковий для всіх коефіцієнтів, тому для визначення їх значимості можна застосувати правило - коефіцієнт значущий, якщо його абсолютна величина більше довірчого інтервалу.

Незначні коеффіціенти виключаємо з рівняння.

Остаточно рівняння регресії має вигляд:

$$
\Delta \mathrm{b}_{\mathrm{i}}<\left|\Delta \mathrm{b}_{\mathrm{ij}}\right|
$$

$$
\begin{gathered}
Y=17.18125-0.55625 x_{1}-0.19375 x_{2}+0.21875 x_{1} x_{2}-0.28125 x_{2} x_{3}+0.28125 x_{1} x_{3}-0.49375 x_{1} x_{2} x_{3} \\
Y=16.625-0.025 x_{2}+0.28125 x_{3}-0.775 x_{2} x_{3}
\end{gathered}
$$

Обчислення розрахункових параметрів оптимізації

Шляхом підстановки відповідних знаків в отримане рівняння регресії повернемося до матриці і перерахуємо рівняння у значущих коефіцієнтах.

Таблиця 4 - Значення коефіцієнтів

\begin{tabular}{|l|l|l|l|}
\hline \multicolumn{1}{|c|}{$\mathrm{Y}_{\mathrm{cp}}$} & \multicolumn{1}{|c|}{$\mathrm{Y}$} & \multicolumn{1}{c|}{$\Delta \mathrm{Y}_{\mathrm{cp}}-\mathrm{Y}_{\mathrm{cp}}$} & \multicolumn{1}{c|}{$\Delta \mathrm{Y}^{2}$} \\
\hline 16.15 & 16.13 & 0.02 & 0.00035 \\
\hline 17.25 & 16.13 & 1.12 & 1.2516 \\
\hline 17.65 & 17.68 & -0.03 & 0.00098 \\
\hline 17.65 & 17.68 & -0.03 & 0.00098 \\
\hline 17.15 & 17.12 & 0.03 & 0.0010 \\
\hline 17.4 & 17.12 & 0.28 & 0.0791 \\
\hline 15.55 & 15.57 & -0.02 & 0.00035 \\
\hline 18.65 & 15.57 & 3.08 & 9.4941 \\
\hline \multicolumn{2}{|l|}{} & \multicolumn{2}{c}{$\sum=10.828$}
\end{tabular}

Побудуємо поверхню відгуку: 
Автоматизація технологічних і бізнес-процесів Volume 12, Issue 1 /2020 http://www.atbp.onaft.edu.ua/

\begin{tabular}{|r|r|r|r|r|r|r|r|r|r|r|r|}
\hline$\times 2$ & -1 & -0.8 & -0.6 & -0.4 & -0.2 & 0 & 0.2 & 0.4 & 0.6 & 0.8 & 1 \\
\hline 1 & 17.1438 & 17.0450 & 16.9463 & 16.8475 & 16.7488 & 16.6500 & 16.5513 & 16.4525 & 16.3538 & 16.2550 & 16.1563 \\
\hline 0.8 & 16.9838 & 16.9160 & 16.8483 & 16.7805 & 16.7128 & 16.6450 & 16.5773 & 16.5095 & 16.4418 & 16.3740 & 16.3063 \\
\hline 0.6 & 16.8238 & 16.7870 & 16.7503 & 16.7135 & 16.6768 & 16.6400 & 16.6033 & 16.5665 & 16.5298 & 16.4930 & 16.4563 \\
\hline 0.4 & 16.6638 & 16.6580 & 16.6523 & 16.6465 & 16.6408 & 16.6350 & 16.6293 & 16.6235 & 16.6178 & 16.6120 & 16.6063 \\
\hline 0.2 & 16.5038 & 16.5290 & 16.5543 & 16.5795 & 16.6048 & 16.6300 & 16.6553 & 16.6805 & 16.7058 & 16.7310 & 16.7563 \\
\hline 0 & 16.3438 & 16.4000 & 16.4563 & 16.5125 & 16.5688 & 16.6250 & 16.6813 & 16.7375 & 16.7938 & 16.8500 & 16.9063 \\
\hline-0.2 & 16.1838 & 16.2710 & 16.3583 & 16.4455 & 16.5328 & 16.6200 & 16.7073 & 16.7945 & 16.8818 & 16.9690 & 17.0563 \\
\hline-0.4 & 16.0238 & 16.1420 & 16.2603 & 16.3785 & 16.4968 & 16.6150 & 16.7333 & 16.8515 & 16.9698 & 17.0880 & 17.2063 \\
\hline-0.6 & 15.8638 & 16.0130 & 16.1623 & 16.3115 & 16.4608 & 16.6100 & 16.7593 & 16.9085 & 17.0578 & 17.2070 & 17.3563 \\
\hline-0.8 & 15.7038 & 15.8840 & 16.0643 & 16.2445 & 16.4248 & 16.6050 & 16.7853 & 16.9655 & 17.1458 & 17.3260 & 17.5063 \\
\hline-1 & 15.5438 & 15.7550 & 15.9663 & 16.1775 & 16.3888 & 16.6000 & 16.8113 & 17.0225 & 17.2338 & 17.4450 & 17.6563 \\
\hline
\end{tabular}

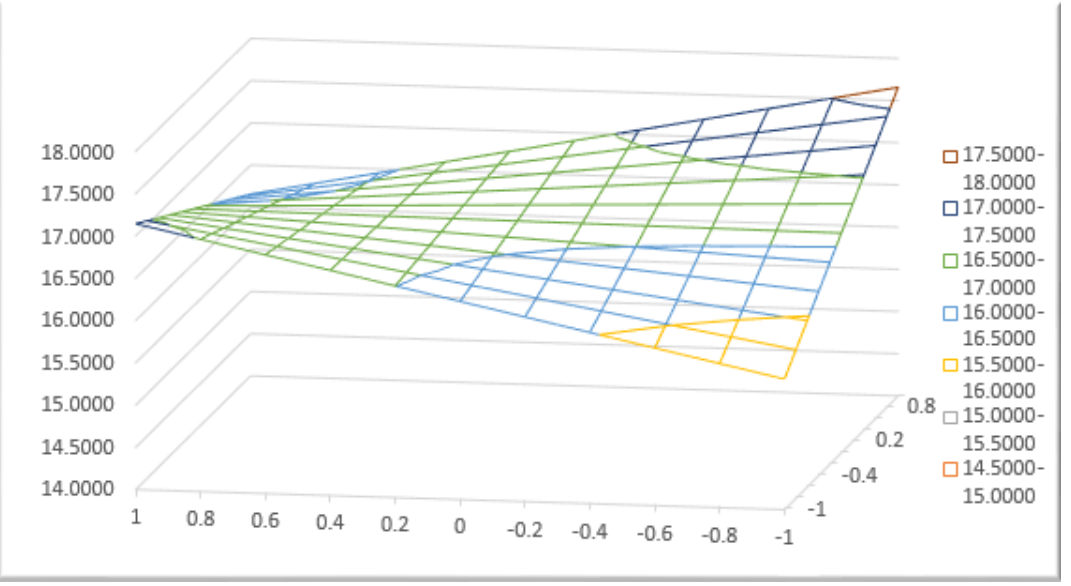

Рис. 7 - Побудова поверхні відгуку

Таблиця 5 - Інтервали варіювання фактора для другого ССККВ

\begin{tabular}{|c|c|c|}
\hline Фактори & Min(-1) & $\operatorname{Max}(+1)$ \\
\hline X1(toc) & 25.9 & 34.6 \\
\hline X2(тзв) & 22.7 & 25.7 \\
\hline X3(тов) & 11.8 & 13.7 \\
\hline
\end{tabular}

Число дослідів для реалізації всіх можливих поєднань рівнів і факторів обчислюється за формулою:

$$
\mathrm{N}=2^{\mathrm{n}}=2^{3}=8,
$$

де $\mathrm{N}$ - кількість експерементів; $\mathrm{n}$ - кількість факторів.

План експерименту наведено у таблиці 6:

Таблиця 6 - План експерименту

\begin{tabular}{|c|c|c|c|c|c|c|c|c|c|c|c|}
\hline$\#(2)$ & $\mathrm{x} 0$ & $\mathrm{x} 1$ & $x 2$ & $x 3$ & $\mathrm{x} 1 \times 2$ & $x 2 \times 3$ & $\mathrm{x} 1 \mathrm{x} 3$ & $x 1 \times 2 \times 3$ & $\mathrm{Y} 1$ & Y2 & Ymed \\
\hline 1 & 1 & 1 & 1 & 1 & 1 & 1 & 1 & 1 & 62 & 62.3 & 62.15 \\
\hline 2 & 1 & -1 & 1 & 1 & -1 & 1 & -1 & -1 & 60 & 59.7 & 59.85 \\
\hline 3 & 1 & 1 & -1 & 1 & -1 & -1 & 1 & -1 & 60 & 59.7 & 59.85 \\
\hline 4 & 1 & -1 & -1 & 1 & 1 & -1 & -1 & 1 & 60 & 59.7 & 59.85 \\
\hline 5 & 1 & 1 & 1 & -1 & 1 & -1 & -1 & -1 & 68 & 68.3 & 68.15 \\
\hline 6 & 1 & -1 & 1 & -1 & -1 & -1 & 1 & 1 & 68 & 67.8 & 67.9 \\
\hline 7 & 1 & 1 & -1 & -1 & -1 & 1 & -1 & 1 & 62 & 61.5 & 61.75 \\
\hline 8 & 1 & -1 & -1 & -1 & 1 & 1 & 1 & -1 & 72 & 71.3 & 71.65 \\
\hline & & & & & & & & & & & 511.15 \\
\hline
\end{tabular}

Рівняння регресії, що описує процес обробки повітря, має вигляд:

$$
\mathrm{Y}=\mathrm{b}_{0}+\mathrm{b}_{1} \mathrm{x}_{1}+\mathrm{b}_{2} \mathrm{x}_{2}+\mathrm{b}_{3} \mathrm{x}_{3}+\mathrm{b}_{12} \mathrm{x}_{1} \mathrm{x}_{2}+\mathrm{b}_{23} \mathrm{x}_{2} \mathrm{x}_{3}+\mathrm{b}_{13} \mathrm{x}_{1} \mathrm{x}_{3}+\mathrm{b}_{123} \mathrm{x}_{1} \mathrm{x}_{2} \mathrm{x}_{2}
$$

Визначення коефіціснтів рівняння регресії

Визначимо вільний член за формулою:

$$
\begin{aligned}
\mathrm{b}_{0} & =\sum \mathrm{Y}_{\mathrm{cp}} / \mathrm{N} \\
\mathrm{b}_{0} & =511.15 / 8
\end{aligned}
$$


Визначимо коефіцієнти взаємодії за формулою:

$$
\mathrm{b}_{1}=\sum \mathrm{x}_{\mathrm{i}} \cdot \mathrm{Y}_{\mathrm{icp}} / \mathrm{N}
$$

Рівняння регресії після розрахунку має вигляд:

$$
Y=63.89375-0.91875 x_{1}+0.61875 x_{2}-3.46875 x_{3}+1.55625 x_{1} x_{2}-0.04375 x_{2} x_{3}+1.49375 x_{1} x_{3}-0.98125 x_{1} x_{2} x_{3}
$$

\section{Перевірка відтворюваності процесу і значущості коефіцієнтів регресії}

Для перевірки відтворюваності про-процесу і проведення статичних оцінок перед-розглядаються паралельні досліди. Якщо кожен досвід повторюється однаковий-ше число раз, то таке повторення називають паралельним дублюванням. При однаковому числі паралельних дослідів на кожному поєднанні рівнів і факто-рів розраховуються построкові дисперсії і перевіряється їх однорідність за критерієм Кохрена. Однорідність перевіряється шляхом вибору максимального значення з порядкової дис-персів і визначення для нього розрахункового кри-терия Кохрена.

Построкові дисперсії розраховуємо за формулою:

$$
\mathrm{S}_{\mathrm{yi}}^{2}=\left(\sum\left(\mathrm{Y}_{1 \text { экс }}-\mathrm{Y}_{\text {ср.экс }}\right)^{\wedge} 2+\left(\mathrm{Y}_{\text {2экс }}-\mathrm{Y}_{\text {ср.экс }}\right)^{\wedge} 2\right) /(\mathrm{H}-1),
$$

де $\mathrm{H}=2$ - кількість паралельних дослідів.

$\mathrm{S}_{\mathrm{y} 1}^{2}=(62-62.15)^{\wedge} 2+(62.3-62.15)^{\wedge} 2 /(2-1)=0.045$

$\mathrm{S}^{2}{ }_{\mathrm{y} 2}=(60-59.8)^{\wedge} 2+(59.7-59.85)^{\wedge} 2 /(2-1)=0.045$

$\mathrm{S}_{\mathrm{y} 3}^{2}=(60-59.8)^{\wedge} 2+(59.7-59.8)^{\wedge} 2 /(2-1)=0.045$

$\mathrm{S}^{2}{ }_{\mathrm{y} 4}=(60-59.8)^{\wedge} 2+(59.7-59.8)^{\wedge} 2 /(2-1)=0.045$

$\mathrm{S}^{2}{ }_{\mathrm{y} 5}=(68-68.15)^{\wedge} 2+(68.3-68.15)^{\wedge} 2 /(2-1)=0.045$

$\mathrm{S}^{2}{ }_{\mathrm{y} 6}=(68-67.9)^{\wedge} 2+(67.8-67.9)^{\wedge} 2 /(2-1)=0.02$

$\mathrm{S}_{\mathrm{y} 7}^{2}=(62-61.75)^{\wedge} 2+(61.5-61.75)^{\wedge} 2 /(2-1)=0.125$

$\mathrm{S}_{\mathrm{y} 8}^{2}=(72-71.65)^{\wedge} 2+(71.3-71.65)^{\wedge} 2 /(2-1)=0.245$

$\sum \mathrm{S}_{\mathrm{y}}^{2}=0.615$

Мах значення $S_{\text {y8 }}^{2}=0.245$

Визначивши максимальне значення порядкової дисперсії обчислюємо для неї розрахунковий критерій Кохрена:

$$
\begin{gathered}
\mathrm{G}_{\mathrm{p}}=\mathrm{S}_{\mathrm{y} \max } / \sum \mathrm{S}_{\mathrm{i}}{ }_{\mathrm{i}} \\
\mathrm{G}_{\mathrm{P}}=0.245 / 0.615=0.4
\end{gathered}
$$

Висновок про однорідність робимо на основі порівняння отриманого розрахункового критерію Кохрена 3 табличним значенням.

Визначимо дисперсію експерименту:

$$
\begin{gathered}
S_{\text {y cp }}^{2}=\sum S_{i}^{2} / N \\
S_{\text {y cp }}^{2}=0.615 / 8=0.077
\end{gathered}
$$

\section{Визначення дисперсії коефіціснтів рівняння регресії}

Для перевірки гіпотези щодо статичної значущості коефіцієнтів рівняння регресії розрахуємо дисперсію коефіцієнтів по формулі:

$$
\begin{gathered}
\mathrm{S}_{\mathrm{bi}}^{2}=\sum \mathrm{S}_{\mathrm{ycp}}^{2} / \mathrm{N} \cdot \mathrm{M}, \\
\mathrm{S}_{\mathrm{bi}}^{2}=0.077 / 8 \cdot 2=0.0048,
\end{gathered}
$$

де $\mathrm{M}=2$ - кількість паралельних серій.

Для оцінки значущості коефіцієнтів з довірчого інтервалу обчислюємо для кожного коефіцієнта за формулою:

$$
\begin{gathered}
\Delta \mathrm{b}_{\mathrm{i}}= \pm \mathrm{t} \cdot \sqrt{ } \mathrm{S}_{\mathrm{bi}}^{2} \\
\Delta \mathrm{b}_{\mathrm{i}}= \pm 2.31 \cdot \sqrt{ } 0.0048= \pm 0.16
\end{gathered}
$$

де $\mathrm{t}=2.31-$ критерій Стьюдента.

Довірчий інтервал $\Delta \mathrm{b}_{\mathrm{i}}$ однаковий для всіх коефіцієнтів, тому для визначення їх значущості можна застосувати правило: коефіцієнт значущий, якщо його абсолютна величина більше довірчого інтервалу. Незначні коефіціенти виключаємо із рівняння.

Остаточно рівняння регресії має вигляд:

$$
\Delta \mathrm{b}_{\mathrm{i}}<\left|\Delta \mathrm{b}_{\mathrm{ij}}\right|
$$

$$
\begin{gathered}
Y=63.89375-0.91875 x_{1}-0.61875 x_{2}-3.46875 x_{3}+1.55625 x_{1} x_{2}+1.493755 x_{1} x_{3}-0.98125 x_{1} x_{2} x_{3} \\
Y=62.975+2.175 x_{2}-1.975 x_{3}-0.98125 x_{2} x_{3}
\end{gathered}
$$

\section{Обчислення розрахункових параметрів отимізації}

Шляхом підстановки відповідних знаків в отримане рівняння регресії повернемося до матриці і перерахуємо рівняння у значущих коефіцієнтів. 
Таблиця 7 - Значення коефіціснтів

\begin{tabular}{|l|l|l|l|}
\hline \multicolumn{1}{|c|}{$\mathrm{Y}_{\mathrm{cp}}$} & \multicolumn{1}{|c|}{$\mathrm{Y}$} & \multicolumn{1}{c|}{$\Delta \mathrm{Y}=\mathrm{Y}_{\mathrm{cp}}-\mathrm{Y}$} & \multicolumn{1}{c|}{$\Delta \mathrm{Y}^{2}$} \\
\hline 62.15 & 62.19 & -0.04 & 0.002 \\
\hline 59.85 & 62.19 & -2.34 & 5.49 \\
\hline 59.85 & 59.81 & 0.04 & 0.002 \\
\hline 59.85 & 59.81 & 0.04 & 0.002 \\
\hline 68.15 & 68.11 & 0.04 & 0.002 \\
\hline 67.9 & 68.11 & -0.21 & 0.04 \\
\hline 61.75 & 61.79 & -0.04 & 0.002 \\
\hline 71.65 & 61.79 & 9.86 & 97.15 \\
\hline
\end{tabular}

Побудуємо поверхню відгуку:

\begin{tabular}{|c|c|c|c|c|c|c|c|c|c|c|c|}
\hline$x 2-\times 3$ & -1 & -0.8 & -0.6 & -0.4 & -0.2 & 0 & 0.2 & 0.4 & 0.6 & 0.8 & 1 \\
\hline 1 & 66.32875 & 66.093 & 65.85725 & 65.6215 & 65.38575 & 65.15 & 64.91425 & 64.6785 & 64.44275 & 64.207 & 63.97125 \\
\hline 0.8 & 65.6975 & 65.501 & 65.3045 & 65.108 & 64.9115 & 64.715 & 64.5185 & 64.322 & 64.1255 & 63.929 & 63.7325 \\
\hline 0.6 & 65.06625 & 64.909 & 64.75175 & 64.5945 & 64.43725 & 64.28 & 64.12275 & 63.9655 & 63.80825 & 63.651 & 63.49375 \\
\hline 0.4 & 64.435 & 64.317 & 64.199 & 64.081 & 63.963 & 63.845 & 63.727 & 63.609 & 63.491 & 63.373 & 63.255 \\
\hline 0.2 & 63.80375 & 63.725 & 63.64625 & 63.5675 & 63.48875 & 63.41 & 63.33125 & 63.2525 & 63.17375 & 63.095 & 63.01625 \\
\hline 0 & 63.1725 & 63.133 & 63.0935 & 63.054 & 63.0145 & 62.975 & 62.9355 & 62.896 & 62.8565 & 62.817 & 62.7775 \\
\hline-0.2 & 62.54125 & 62.541 & 62.54075 & 62.5405 & 62.54025 & 62.54 & 62.53975 & 62.5395 & 62.53925 & 62.539 & 62.53875 \\
\hline-0.4 & 61.91 & 61.949 & 61.988 & 62.027 & 62.066 & 62.105 & 62.144 & 62.183 & 62.222 & 62.261 & 62.3 \\
\hline-0.6 & 61.27875 & 61.357 & 61.43525 & 61.5135 & 61.59175 & 61.67 & 61.74825 & 61.8265 & 61.90475 & 61.983 & 62.06125 \\
\hline-0.8 & 60.6475 & 60.765 & 60.8825 & 61 & 61.1175 & 61.235 & 61.3525 & 61.47 & 61.5875 & 61.705 & 61.8225 \\
\hline-1 & 60.01625 & 60.173 & 60.32975 & 60.4865 & 60.64325 & 60.8 & 60.95675 & 61.1135 & 61.27025 & 61.427 & 61.58375 \\
\hline
\end{tabular}

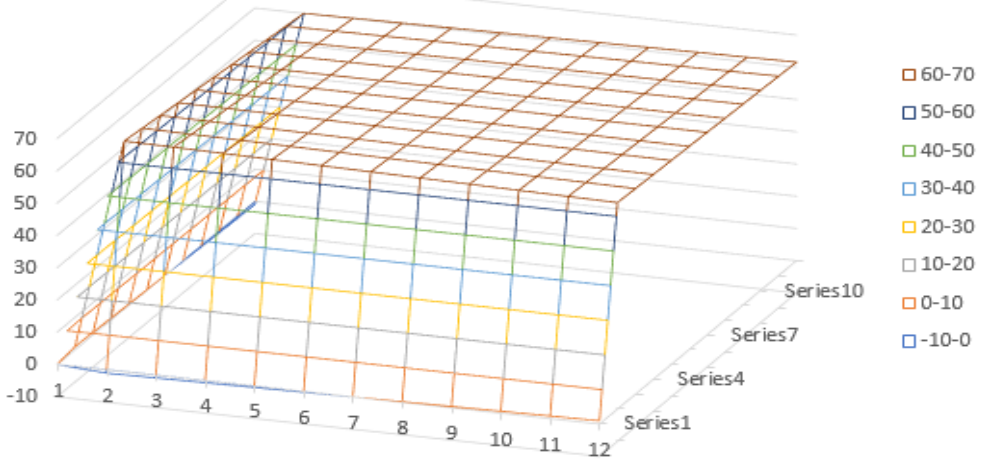

Рис. 8 - Побудова поверхні відгуку

Таблиця 8 - Інтервали варіювання фактора для другого ССККВ, що працює самостійно

\begin{tabular}{|c|c|c|}
\hline Фактори & $\operatorname{Min}(-1)$ & $\operatorname{Max}(+1)$ \\
\hline X1(тос) & 19.2 & 23.3 \\
\hline X2(тзв) & 14 & 21 \\
\hline X3(тов) & 10.2 & 12.1 \\
\hline
\end{tabular}

План експерименту наведено у таблиці 9:

Таблиця 9 - План експерименту

\begin{tabular}{|c|c|c|c|c|c|c|c|c|c|c|c|}
\hline & $x 0$ & $\mathrm{x} 1$ & $\times 2$ & $\times 3$ & $x 1 \times 2$ & $\times 2 \times 3$ & $x 1 \times 3$ & $x 1 \times 2 \times 3$ & Y1 & Y2 & Ymed \\
\hline 1 & 1 & 1 & 1 & 1 & 1 & 1 & 1 & 1 & 50 & 50.3 & 50.15 \\
\hline 2 & 1 & -1 & 1 & 1 & -1 & 1 & -1 & -1 & 48 & 47.7 & 47.85 \\
\hline 3 & 1 & 1 & -1 & 1 & -1 & -1 & 1 & -1 & 48 & 47.7 & 47.85 \\
\hline 4 & 1 & -1 & -1 & 1 & 1 & -1 & -1 & 1 & 33 & 32.7 & 32.85 \\
\hline 5 & 1 & 1 & 1 & -1 & 1 & -1 & -1 & -1 & 33 & 33.3 & 33.15 \\
\hline 6 & 1 & -1 & 1 & -1 & -1 & -1 & 1 & 1 & 19 & 18.8 & 18.9 \\
\hline 7 & 1 & 1 & -1 & -1 & -1 & 1 & -1 & 1 & 25 & 24.5 & 24.75 \\
\hline 8 & 1 & -1 & -1 & -1 & 1 & 1 & 1 & -1 & 15 & 14.3 & 14.65 \\
\hline & & & & & & & & & & & 270.15 \\
\hline
\end{tabular}


Запишемо для повного фактичного експерименту рівняння регресії, яке описує процес обробки повітря:

$$
\mathrm{Y}=\mathrm{b}_{0}+\mathrm{b}_{1} \mathrm{x}_{1}+\mathrm{b}_{2} \mathrm{x}_{2}+\mathrm{b}_{3} \mathrm{x}_{3}+\mathrm{b}_{12} \mathrm{x}_{1} \mathrm{x}_{2}+\mathrm{b}_{23} \mathrm{x}_{2} \mathrm{x}_{3}+\mathrm{b}_{13} \mathrm{x}_{1} \mathrm{x}_{3}+\mathrm{b}_{123} \mathrm{x}_{1} \mathrm{x}_{2} \mathrm{x}_{2}
$$

Визначення коефіціснтів рівняння регресії

Визначимо вільний член за формулою:

Визначимо коефіцієнти взаємодії за формулою:

$$
\begin{aligned}
\mathrm{b}_{0} & =\sum \mathrm{Y}_{\mathrm{cp}} / \mathrm{N} \\
\mathrm{b}_{0} & =270.15 / 8
\end{aligned}
$$

Рівняння регресії після розрахунку має вигляд:

$$
\mathrm{b}_{1}=\sum \mathrm{x}_{\mathrm{i}} \cdot \mathrm{Y}_{\mathrm{icp}} / \mathrm{N}
$$

$$
Y=33.76875+5.20625 x_{1}+3.74375 x_{2}+10.90625 x_{3}-1.06875 x_{1} x_{2}+0.58125 x_{2} x_{3}-0.88125 x_{1} x_{3}-2.10625 x_{1} x_{2} x_{3}
$$

\section{Перевірка відтворюваності процесу і значущості коефіцієнтів регресії}

Для перевірки відтворюваності процесу і проведення статичних оцінок розглядаються паралельні досліди. Якщо кожен досвід повторюється однакове число разів, то таке повторення називають паралельним дублюванням.

При однаковому числі паралельних дослідів на кожному поєднанні рівнів і факторів розраховуються построкові дисперсії і перевіряється їх однорідність за критерієм Кохрена. Однорідність перевіряється шляхом вибору максимального значення з порядкової дисперсії і визначення для нього розрахункового критерія Кохрена.

Построкові дисперсії розраховуємо за формулою:

$$
\mathrm{S}_{\text {уi }}^{2}=\left(\sum\left(\mathrm{Y}_{1 э к с}-\mathrm{Y}_{\text {ср.экс }}\right)^{\wedge} 2+\left(\mathrm{Y}_{2 э к с}-\mathrm{Y}_{\text {ср.экс }}\right)^{\wedge} 2\right) /(\mathrm{H}-1)
$$

де $\mathrm{H}=2$ - кількість паралельних дослідів.

$\mathrm{S}_{\mathrm{y1}}^{2}=(50-50.15)^{\wedge} 2+(50.3-50.15)^{\wedge} 2 /(2-1)=0.045$

$\mathrm{S}^{2}{ }_{\mathrm{y} 2}=(48-47.85)^{\wedge} 2+(47.7-47.85)^{\wedge} 2 /(2-1)=0.045$

$\mathrm{S}^{2}{ }_{\mathrm{y} 3}=(48-47.85)^{\wedge} 2+(47.7-47.85)^{\wedge} 2 /(2-1)=0.045$

$\mathrm{S}^{2}{ }_{\mathrm{y} 4}=(33-32.85)^{\wedge} 2+(32.7-32.85)^{\wedge} 2 /(2-1)=0.045$

$\mathrm{S}^{2}{ }_{\mathrm{y} 5}=(33-33.15)^{\wedge} 2+(33.3-33.15)^{\wedge} 2 /(2-1)=0.045$

$\mathrm{S}^{2}{ }_{\mathrm{y} 6}=(19-18.9)^{\wedge} 2+(18.8-18.9)^{\wedge} 2 /(2-1)=0.02$

$\mathrm{S}^{2}{ }_{\mathrm{y} 7}=(25-24.75)^{\wedge} 2+(24.5-24.75)^{\wedge} 2 /(2-1)=0.125$

$\mathrm{S}_{\mathrm{y} 8}^{2}=(15-14.65)^{\wedge} 2+(14.3-14.65)^{\wedge} 2 /(2-1)=0.245$

$\sum \mathrm{S}_{\mathrm{y}}^{2}=0.615$

Мах значення $\mathrm{S}_{\mathrm{y} 8}^{2}=0.245$

Визначивши максимальне значення порядкової дисперсії обчислюємо для нього розрахунковий критерій Кохрена:

$$
\begin{gathered}
\mathrm{G}_{\mathrm{p}}=\mathrm{S}_{\mathrm{y} \max }^{2} / \sum \mathrm{S}_{\mathrm{i}}^{2} \\
\mathrm{G}_{\mathrm{P}}=0.245 / 0.615=0.4
\end{gathered}
$$

Висновок про однорідність робимо на основі порівняння отриманого розрахункового критерію Кохрена 3 табличним значенням.

$$
\begin{gathered}
\text { Визначимо дисперсію експерименту: } \\
\mathrm{S}_{\text {y ср }}^{2}=\sum \mathrm{S}_{\mathrm{i}}^{2} / \mathrm{N} \\
\mathrm{S}_{\text {y cp }}^{2}=0.615 / 8=0.077
\end{gathered}
$$

\section{Визначення дисперсії коефіціснтів рівняння регресії}

Для перевірки гіпотези щодо статичної значущості коефіцієнтів рівняння регресії розрахуємо дисперсію коефіцієнтів:

$$
\begin{gathered}
\mathrm{S}_{\mathrm{bi}}^{2}=\sum \mathrm{S}_{\mathrm{ycp}}^{2} / \mathrm{N} \cdot \mathrm{M} \\
\mathrm{S}_{\mathrm{bi}}^{2}=0.077 / 8 \cdot 2=0.0048
\end{gathered}
$$

де $\mathrm{M}=2$ - кількість паралельних серій.

Для оцінки значущості коефіцієнтів 3 довірчого інтервалу обчислюємо для кажного коефіцієнта за формулою:

$$
\begin{gathered}
\Delta \mathrm{b}_{\mathrm{i}}= \pm \mathrm{t} \cdot \sqrt{ } \mathrm{S}_{\mathrm{bi}} \\
\Delta \mathrm{b}_{\mathrm{i}}= \pm 2.31 \cdot \sqrt{ } 0.0048= \pm 0.16
\end{gathered}
$$

де $\mathrm{t}=2.31$ - критерій Стьюдента.

Незначні коефіціенти виключаємо із рівняння.

Остаточно рівняння регресії має вигляд:

$$
\begin{gathered}
Y=38.975+3.74375 x_{2}+10.90625 x_{3}-1.06875 x_{2}+0.58125 x_{2} x_{3}-0.88125 x_{3}-2.10625_{1} x_{2} x_{3} \\
Y=38.975+2.675 x_{2}+10.025 x_{3}-1.525 x_{2} x_{3}
\end{gathered}
$$


Обчислення розрахункових параметрів оптимізації

Шляхом підстановки відповідних знаків в отримане рівняння регресії повернемося до матриці і перерахуємо рівняння у значимих коефіцієнтів.

Таблиця 10 - Значення коефіцієнтів

\begin{tabular}{|l|l|l|l|}
\hline \multicolumn{1}{|c|}{$\mathrm{Y}_{\mathrm{cp}}$} & \multicolumn{1}{c|}{$\mathrm{Y}$} & \multicolumn{1}{c|}{$\Delta \mathrm{Y}=\mathrm{Y}_{\mathrm{cp}}-\mathrm{Y}$} & \multicolumn{1}{c|}{$\Delta \mathrm{Y}^{2}$} \\
\hline 50.15 & 50.15 & 0 & 0 \\
\hline 47.85 & 50.15 & -2.3 & 5.29 \\
\hline 47.85 & 47.85 & 0 & 0 \\
\hline 32.85 & 47.85 & -15 & 225 \\
\hline 33.15 & 33.15 & 0 & 0 \\
\hline 18.9 & 33.15 & -14.25 & 203.0625 \\
\hline 24.75 & 24.75 & 0 & 0 \\
\hline 14.65 & 24.75 & -10.1 & 102.01 \\
\hline
\end{tabular}

Побудуємо поверхню відгуку

\begin{tabular}{|r|r|r|r|r|r|r|r|r|r|r|r|}
\hline$\times 2 \times 3$ & -1 & -0.8 & -0.6 & -0.4 & -0.2 & 0 & 0.2 & 0.4 & 0.6 & 0.8 & 1 \\
\hline 1 & 66.32875 & 66.093 & 65.85725 & 65.6215 & 65.38575 & 65.15 & 64.91425 & 64.6785 & 64.44275 & 64.207 & 63.97125 \\
\hline 0.8 & 65.6975 & 65.501 & 65.3045 & 65.108 & 64.9115 & 64.715 & 64.5185 & 64.322 & 64.1255 & 63.929 & 63.7325 \\
\hline 0.6 & 65.06625 & 64.909 & 64.75175 & 64.5945 & 64.43725 & 64.28 & 64.12275 & 63.9655 & 63.80825 & 63.651 & 63.49375 \\
\hline 0.4 & 64.435 & 64.317 & 64.199 & 64.081 & 63.963 & 63.845 & 63.727 & 63.609 & 63.491 & 63.373 & 63.255 \\
\hline 0.2 & 63.80375 & 63.725 & 63.64625 & 63.5675 & 63.48875 & 63.41 & 63.33125 & 63.2525 & 63.17375 & 63.095 & 63.01625 \\
\hline 0 & 63.1725 & 63.133 & 63.0935 & 63.054 & 63.0145 & 62.975 & 62.9355 & 62.896 & 62.8565 & 62.817 & 62.7775 \\
\hline-0.2 & 62.54125 & 62.541 & 62.54075 & 62.5405 & 62.54025 & 62.54 & 62.53975 & 62.5395 & 62.53925 & 62.539 & 62.53875 \\
\hline-0.4 & 61.91 & 61.949 & 61.988 & 62.027 & 62.066 & 62.105 & 62.144 & 62.183 & 62.222 & 62.261 & 62.3 \\
\hline-0.6 & 61.27875 & 61.357 & 61.43525 & 61.5135 & 61.59175 & 61.67 & 61.74825 & 61.8265 & 61.90475 & 61.983 & 62.06125 \\
\hline-0.8 & 60.6475 & 60.765 & 60.8825 & 61 & 61.1175 & 61.235 & 61.3525 & 61.47 & 61.5875 & 61.705 & 61.8225 \\
\hline-1 & 60.01625 & 60.173 & 60.32975 & 60.4865 & 60.64325 & 60.8 & 60.95675 & 61.1135 & 61.27025 & 61.427 & 61.58375 \\
\hline
\end{tabular}

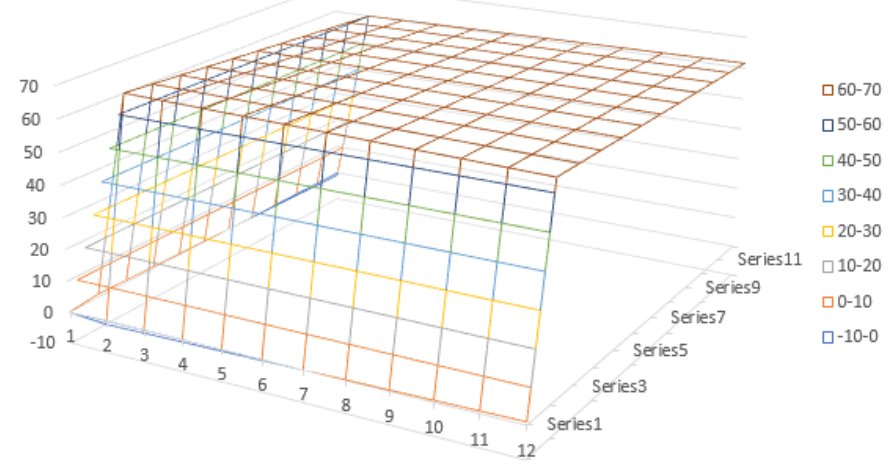

\section{4. Висновок}

Запропонована система з використанням програмованих логічних контролерів дозволить:

- уникнути прийняття суб'єктивних рішень з управління, і як слідство - відповідальність за енергоефективну та екологічну складову процесу з експлуатації ССККП людиною - оператором;

- збільшити енергетичну ефективність використання ССККП за допомогою оптимального управління програмованих логічних контролерів, в умовах, де постійно змінюються зовнішні гідрометеорологічні умови.

- в автоматичному режимі отримувати дані та можливість їх корегування, з холодопродуктивності, споживання електричної енергії у реальному часі, а також дані з питомої витрати енергії на вироблення холоду, кроме того, користувач отрімує дінаміку змін ціх величин за обраний період часу.

\section{Список використаних джерел}

[1] Загоруйко В.А., Голиков А.А. Судовая холодильная техника-Киев: Наукова думка, 2000.- 607 с.

[2] Очеретяный Ю.А. Техническая эксплуатация судовых холодильных установок и систем кондиционирования // Учебное пособие для курсантов и студентов высших морских учебных заведений 2014. - Одеса: Изд. ОНМА, 204 с.

[3] Очеретяный Ю.А., Живица В.И., Белый В.Н., Онищенко О.А., Вайнфельд Э.Й. Концепция системы компьютерного мониторинга и технической диагностики рефрижераторной установки судна // Судовые энергетические установки: науч. -техн. сб. - 2011. - Вып. 28. Одесса: ОНМА - С. 5 - 11. 
[4] Очеретяный Ю.А. Определение изменений теплотехнических характеристик судовых холодильных установок в процессе эксплуатации // Холодильна техніка і технологія. - 2013. - Вип. 2 (142). - С. 15-19.

[5] Очеретяный Ю.А. Определение отклонений функционирования судовой холодильной установки в процессе эксплуатации // Холодильна техніка і технологія. - 2013. - Вип. 3 (143). - С. 10-14.

[6] Очеретяный Ю.А., Живица В.И., Онищенко О.А., Вайнфельд Э.Й., Тюхай Д.С. Разработка системы измерения энергетических показателей компрессионной холодильной установки // Харчова наука і технологія. - 2011. - Вип. 4(17). - C. 107 - 109.

[7] Очеретяный Ю.А. Определение термодинамических показателей судовой холодильной установки в процессе эксплуатации // Проблеми техніки. - 2013. - Вип. 2. - С. 119 - 125.

\title{
References
}

[1] Zagoruyko V. A., Golikov A. A. Ship refrigeration equipment. Kiev: Naukova Dumka, 2000. 607p.

[2] Ocheretyanyy Y. Technical operation of ship refrigeration units and air conditioning systems. Textbook for cadets and students of higher marine educational institutions, 2014. Odessa: ONMA Publishing House, $204 \mathrm{p}$.

[3] Ocheretyany Y. A., Zhivitsa V. I., Belyi V. N., Onishchenko O. A., Weinfeld E. Y. The concept of a system for computer monitoring and technical diagnostics of a refrigerator installation of a ship. Ship power plants, 2011. Issue. 28. Pp. 5-11.

[4] Ocheretyanyy Y. Determination of changes in the thermal characteristics of ship refrigeration units during operation. Refrigeration Engineering and technology. 2013. No. 2(142). Pp. 15-19.

[5] Ocheretyanyy Y. Determination of deviations of functioning of a ship refrigeration unit during operation. Refrigeration Engineering and technology. 2013. No. 3(143). Pp. 10-14.

[6] Ocheretyanyy Y. A., Zhivitsa V. I., Onishchenko O. A., Weinfeld E. I., Tyukhai D. S. Development of a system for measuring the energy performance of a compression refrigeration unit. Food science and technology. 2011. No. 4(17). Pp. 107-109.

[7] Ocheretyany Y. Determination of thermodynamic indicators of a ship refrigeration unit during operation. Problems of technology. 2013. No. 2. Pp. 119-125.

\section{САР ИНВАРИАНТНАЯ К КОНТРОЛИРУЕМЫМ ВОЗМУЩЕНИЯМ С ПРОГНОЗИРОВАНИЕМ СИГНАЛА КОРРЕКЦИИ ПО КУБИЧЕСКОМУ СПЛАЙНУ}

\author{
М. Т. Степанов ${ }^{1}$, В. А. Хобин ${ }^{2}$ \\ ${ }^{1,2}$ Одеська національна академія харчових технологій, Одеса, Україна \\ ORCID: ${ }^{1}$ https://orcid.org/0000-0003-1297-5537, 2 https://orcid.org/0000-0003-0238-8371 \\ e-mail: ${ }^{1}$ stepanov197818@gmail.com; ${ }^{2}$ khobin@onaft.edu.ua
}

Copyright (C) 2020 by author and the journal "Automation of technological and business - processes. This work is licensed under the Creative Commons Attribution International License (CC BY). http://creativecommons.org/licanses/by/4.0

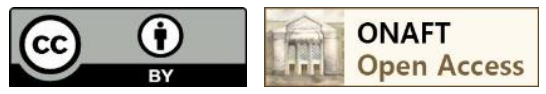

DOI: https://doi.org/10.15673/atbp.v12i1.1705

Аннотация. В статье рассматривается система автоматического регулирования, реализующая комбинированный принцип управления инвариантная относительно контролируемых возмущений. В математических моделях корректирующих связей систем автоматического регулирования инвариантных к контролируемым возмуще-ниям часто присутствуют физически не реализуемые звенья чистого опережения. В инженерной практике для прогнозирования сигнала коррекции на время вперед такие звенья приближенно заменяют форсирующими звеньями. В качестве альтернативы такому подходу предлагается вести прогнозирование сигнала коррекции на основе кубического сплайна. Проведенный анализ показывает, что отдельные участки траектории движения сигнала могут быть представлены непрерывными, многократно дифференцируемыми функциями (например, кубическим сплайном). 